\title{
Consumer Preference and Satisfaction with Reference to Women Apparels at Max Store
}

\author{
A. Sandhya Rani, Budampati. V. S. Sowmya
}

\begin{abstract}
The trend of fashion apparels is growing rapidly. Women consumers are spending more across products and are obsessive about trendy apparels. The study focuses to examine the consumer preference and satisfaction with reference to women apparel at Max store. Primary data is obtained from survey questionnaire using convenience sampling method. Hypothesis is framed to analyse if there is a significant influence of age and income on consumer preference and satisfaction towards women apparels at max store at $A S$ Rao Nagar. Primary data is collected from 150 respondents using convenience sampling. Chi square test is used to analyze the data. Results have indicated that there is no significant influence of age and income on consumer preference and satisfaction.
\end{abstract}

Keywords: Age, Consumer Preference, Consumer Satisfaction, Income

\section{INTRODUCTION}

Consumer preference is used primarily to choose an option that has the best anticipated worth amongst a lot of choices by the purchasers to satisfy his/her wants or desires. Preferences show options among extra valued choices available. The preference of the purchaser is the outcome of their behaviour that they reveal during search, purchase and dispose of products. Consumer satisfaction measures how well the expectations of a consumer concerning a product or a service provided by companies have been met. It is an abstract concept that involves factors such as product price, product quality, service price, service quality and location of product or service purchased.

Satisfaction of consumer after purchase depends on performance of product through expectations. Satisfaction or dissatisfaction of consumer is derived by comparing the actual performance of product with the performance that the consumer expects out of it. Customers make their expectations from the service quality, communications, delivery, references and past experiences. All these are considered by the management so as to match consumer expectations with their perceptions. The interpretation of these factors will be helpful by reaching expected level of consumer satisfaction.

Problem recognition occurs while a consumer finds an unmet want and refers toward consumers looking for changes on present states when they have better understanding of dissatisfaction. The awareness of dissatisfaction results to new demand that is generated as

Revised Manuscript Received on September 10, 2019.

Dr. A. Sandhya Rani, School of Management Studies, Sreenidhi Institute of Science and Technology, Hyderabad - 501 301, Telangana, India

(E-mail: sandhyarania @ sreenidhi.edu.in)

Budampati. V. S. Sowmya, School of Management Studies, Sreenidhi Institute of Science and Technology, Hyderabad - 501 301, Telangana, India

(E-mail: sowmyab@sreenidhi.edu.in) result of internal factors and external factors for appare store, instantly related inner reasons can be consumption intention and consumption belief; external reasons can be family, friends and promotional activities. Max, a division of lifestyle India Pvt .Ltd., opened its $1^{\text {st }}$ store in Indore in the year 2006. In India, Max has more than 200 stores across 80 cities. Max is brand with its own label merchandise that is created by in house designers for every season. Max also launched the Max emerging star in 2017 in 4 smart cities across India. Max won the fashion retailer of the year at the franchisee India Star Retailer Awards 2017. Max was recognised by the great places to work institute as one of the premier brands.

A study by VIDYA B PANICKER, KHALIL AHMAD MOHAMMAD (2017) [1] confirmed that women are enormously fussy about their apparels or garments. With a growing number of women in India, the industry is on the pathway of extraordinary escalation, women spend a considerable amount of their income for purchase of apparels. POONGODI AND M. GOKULAPRIYA (2017) [2] in their analysis studied the source of awareness, preference, attributes and factors influencing purchasing behaviour of girls of college towards apparel buying in Pollachi taluk. Brand, durability, design, price, wider choice, colour, look, offers and discounts, location, size, fashionable, quality, material and comfort are the attributes. TANVI GUPTA, J.K.BATRA (2017) [3] states that there exists important link between demographic variables; income, marital status, education and the psychographic buying pattern of customers for women apparels as well as accessories in Delhi malls.

\section{RESEARCH METHODOLOGY}

Numerous changes and developments are taking place all around with the entire firms and industries including Apparel industry of women with an intention to speed up with the changes and diverse wants of people. Marketers realised that the effectiveness in fulfilling needs of consumers directly impacts profitability. The purchasing behaviour and preferences of women apparel are changing according to changes of generation and time. The better they understand the determinants underlying the behaviour of consumer the more they will be able to develop marketing strategies effectively to meet consumer wants. The main objectives of the study are to examine the consumer preference and satisfaction with reference to women apparel at Max store and to study the influence of age and income on consumer satisfaction of women. A hypothesis is framed

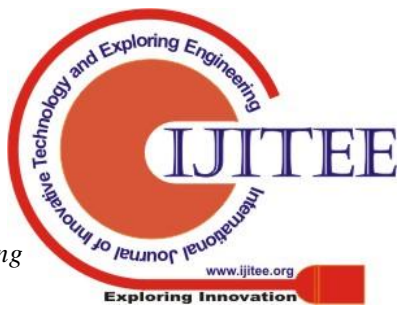


to analyse if there is a significant influence of age and income on consumer preference and satisfaction of women apparels at Max store at A S Rao Nagar. Primary data is collected from 150 respondents using convenience sampling through questionnaire. Chi square test is used to analyze the data.

\section{RESULTS}

Table No:1

\section{Frequency Of Visit - Age Wise}

\begin{tabular}{|c|c|c|c|c|c|c|}
\hline & \multicolumn{4}{|c|}{ FREQUENCY OF VISITING } & \multirow[b]{2}{*}{ Total } \\
\hline & & Weekly & $\begin{array}{l}15 \\
\text { days }\end{array}$ & $\begin{array}{l}\text { Mon } \\
\text { thly }\end{array}$ & $\begin{array}{l}\text { Occasion } \\
\text { al }\end{array}$ & \\
\hline \multirow{5}{*}{$\begin{array}{l}\text { A } \\
\text { G } \\
\text { E }\end{array}$} & $\begin{array}{l}18-22 \\
\text { yrs }\end{array}$ & 2 & 3 & 30 & 29 & 64 \\
\hline & \begin{tabular}{|l}
$23-27$ \\
yrs
\end{tabular} & 0 & 3 & 22 & 14 & 39 \\
\hline & \begin{tabular}{|l|}
$28-32$ \\
$\mathrm{yrs}$
\end{tabular} & 1 & 1 & 8 & 11 & 21 \\
\hline & $\begin{array}{l}33-37 \\
\text { yrs }\end{array}$ & 0 & 0 & 5 & 5 & 10 \\
\hline & $\begin{array}{l}\text { more } \\
\text { than } 37 \\
\text { yrs }\end{array}$ & 1 & 0 & 4 & 11 & 16 \\
\hline \multicolumn{2}{|c|}{ Total } & 4 & 7 & 69 & 70 & 150 \\
\hline
\end{tabular}

From table number 1 it is observed that out of a sample of 150,64 respondents fall under the age group of 18-22 yrs. Among them 30 respondents visit the store monthly and 29 visit occasionally. 39 respondents fall under the age group of 23-27 yrs. Among them 22 respondents visit monthly and 14 respondents visit occasionally.

Table no: 2

Type Of Purchase - Age Wise

\begin{tabular}{|c|c|c|c|c|c|}
\hline & & $\begin{array}{l}\text { Planne } \\
\text { d } \\
\text { purcha } \\
\text { ses }\end{array}$ & $\begin{array}{l}\text { Impulsi } \\
\text { ve }\end{array}$ & $\begin{array}{l}\text { Other } \\
\text { reasons }\end{array}$ & \\
\hline \multirow{5}{*}{ AGE } & $18-22$ yrs & 27 & 36 & 1 & 64 \\
\hline & $23-27$ yrs & 15 & 24 & 0 & 39 \\
\hline & $28-32$ yrs & 9 & 12 & 0 & 21 \\
\hline & $33-37$ yrs & 6 & 4 & 0 & 10 \\
\hline & \begin{tabular}{|l} 
More than \\
37 yrs
\end{tabular} & 7 & 9 & 0 & 16 \\
\hline \multicolumn{2}{|l|}{ Total } & 64 & 85 & 1 & 150 \\
\hline
\end{tabular}

From table number 2 , it is observed that out of a sample of 150, 64 respondents fall under the age group of 18-22 yrs. Of those 27 respondents plan their purchases and remaining make an impulsive purchase decision. 39 respondents fall under age group of 23-27 yrs. Among them, 15 respondents go on a planned purchase.
Table No: 3

Consumer Preference With Reference To Age Chisquare Analysis

\begin{tabular}{|l|l|l|l|}
\hline Factors & Df & Asymp sig & $\begin{array}{l}\text { Significant/ } \\
\text { Insignificant }\end{array}$ \\
\hline Low price & 16 & 0.019 & Significant \\
\hline $\begin{array}{l}\text { Available of various } \\
\text { brands }\end{array}$ & 12 & 0.042 & Significant \\
\hline High Quality & 8 & 0.242 & Insignificant \\
\hline Comfort sizes & 12 & 0.058 & Insignificant \\
\hline $\begin{array}{l}\text { Latest styles and } \\
\text { designs }\end{array}$ & 12 & 0.326 & Insignificant \\
\hline Color Guarantee & 16 & 0.667 & Insignificant \\
\hline Discounts and offers & 12 & 0.144 & Insignificant \\
\hline Exchange policy & 16 & 0.196 & Insignificant \\
\hline Convenient location & 12 & 0.473 & Insignificant \\
\hline Reception & 12 & 0.307 & Insignificant \\
\hline Billing Queue & 12 & 0.510 & Insignificant \\
\hline Parking Place & 12 & 0.181 & Insignificant \\
\hline Wider Choice & 12 & 0.927 & Insignificant \\
\hline Ambience & 8 & 0.242 & Insignificant \\
\hline
\end{tabular}

14 factors are considered for the study to examine the significant influence of age on consumer preferences. Analysis is done using chi square test. It is observed from table number 3 that out of 14 factors only two factors i.e., low price and availability of brands have shown significance with values 0.01 and 0.04 , which are less than the significant value 0.05 . Remaining 12 factors show insignificance indicating that there is no significant influence of age on consumer preferences. Hence Null Hypothesis is accepted.

Table No: 4

Consumer Satisfaction With Reference To Age Chisquare Analysis

\begin{tabular}{|l|l|l|l|}
\hline Factors & Df & Asymp sig & $\begin{array}{l}\text { Significant/ } \\
\text { Insignificant }\end{array}$ \\
\hline Low price & 12 & 0.245 & Insignificant \\
\hline $\begin{array}{l}\text { Available of } \\
\text { various } \\
\text { brands }\end{array}$ & 12 & 0.684 & Insignificant \\
\hline High Quality & 12 & 0.049 & Significant \\
\hline Comfort sizes & 12 & 0.719 & Insignificant \\
\hline $\begin{array}{l}\text { Latest styles } \\
\text { and designs }\end{array}$ & 8 & 0.719 & Insignificant \\
\hline $\begin{array}{l}\text { Color } \\
\text { Guarantee }\end{array}$ & 16 & 0.207 & Insignificant \\
\hline $\begin{array}{l}\text { Discounts and } \\
\text { offers }\end{array}$ & 12 & 0.015 & Significant \\
\hline $\begin{array}{l}\text { Exchange } \\
\text { policy }\end{array}$ & 12 & 0.306 & Insignificant \\
\hline $\begin{array}{l}\text { Convenient } \\
\text { location }\end{array}$ & 12 & 0.766 & Insignificant \\
\hline
\end{tabular}




\begin{tabular}{|l|l|l|l|}
\hline Reception & 12 & 0.571 & Insignificant \\
\hline Billing Queue & 12 & 0.378 & Insignificant \\
\hline Parking Place & 16 & 0.420 & Insignificant \\
\hline Wider Choice & 16 & 0.151 & Insignificant \\
\hline Ambience & 16 & 0.332 & Insignificant \\
\hline
\end{tabular}

The analysis indicates that out of 14 factors only two factors i.e., High quality and discounts \& offers have shown significance with values 0.04 and 0.01 , which are less than the significant value 0.05 . The remaining 12 alternatives shows insignificance indicating there is no significant influence of age on consumer Satisfaction. Hence Null Hypothesis is accepted.

Table No: 5

Frequency Of Visit - Income Wise

\begin{tabular}{|c|c|c|c|c|c|}
\hline \multirow[b]{2}{*}{ INCOME } & \multicolumn{4}{|c|}{ FREQUENCY OF VISITING } & \multirow[b]{2}{*}{ Total } \\
\hline & weekly & \begin{tabular}{|l}
15 \\
days
\end{tabular} & $\begin{array}{l}\text { Mont } \\
\text { hly }\end{array}$ & $\begin{array}{l}\text { occasi } \\
\text { onal }\end{array}$ & \\
\hline NO INCOME & 3 & 3 & 31 & 48 & 85 \\
\hline below 20000 & 0 & 1 & 3 & 5 & 9 \\
\hline $20000-40000$ & 1 & 2 & 16 & 11 & 30 \\
\hline $40000-60000$ & 0 & 1 & 14 & 3 & 18 \\
\hline more than 60000 & 0 & 0 & 5 & 3 & 8 \\
\hline Total & 4 & 7 & 69 & 70 & 150 \\
\hline
\end{tabular}

From the above table number 5 , it is observed that out of 150 respondents, 85 respondents who are home makers and students fall under the no income category. Among them, 31 respondents visit monthly and 48 visit occasionally. 48 respondents fall under 20000-60000 income category, of them 30 respondents visit monthly and 14 respondents visit occasionally.

Table No: 6

Type Of Purchase - Income Wise

\begin{tabular}{|l|l|l|l|l|l|}
\hline \multicolumn{2}{|l|}{} & $\begin{array}{l}\text { planne } \\
\text { d }\end{array}$ & $\begin{array}{l}\text { Impulsiv } \\
\text { e }\end{array}$ & $\begin{array}{l}\text { Other } \\
\text { reasons }\end{array}$ & \\
\hline \multirow{5}{*}{$\begin{array}{l}\text { INCOM } \\
\text { E }\end{array}$} & NO INCOME & 38 & 46 & 1 & 85 \\
\cline { 2 - 7 } & below 20000 & 4 & 5 & 0 & 9 \\
\cline { 2 - 7 } & $20000-40000$ & 11 & 19 & 0 & 30 \\
\cline { 2 - 7 } & $40000-60000$ & 7 & 11 & 0 & 18 \\
\cline { 2 - 7 } & $\begin{array}{l}\text { more than } \\
60000\end{array}$ & 4 & 0 & 8 \\
\hline Total & 64 & 85 & 1 & 150 \\
\hline
\end{tabular}

From the above table number 6 , it is observed that out of 150 respondents, 85 respondents fall under no income category, among them 38 respondents plan their purchases and 46 respondents don't plan their purchases.
Table No: 7

Consumer Preference With Reference To Income Chisquare Analysis

\begin{tabular}{|l|l|l|l|}
\hline Factors & Df & $\begin{array}{l}\text { Asymp } \\
\text { sig }\end{array}$ & $\begin{array}{l}\text { Significant/ } \\
\text { Insignificant }\end{array}$ \\
\hline Low price of & 12 & 0.411. & Insignificant \\
\hline $\begin{array}{l}\text { Available } \\
\text { various brands }\end{array}$ & 8 & 0.667 & Insignificant \\
\hline High Quality & 12 & 0.008 & Significant \\
\hline Comfort sizes & 12 & 0.477 & Insignificant \\
\hline $\begin{array}{l}\text { Latest styles and } \\
\text { designs }\end{array}$ & 16 & 0.018 & Significant \\
\hline Colour Guarantee & 12 & 0.107 & Insignificant \\
\hline $\begin{array}{l}\text { Discounts and } \\
\text { offers }\end{array}$ & 12 & 0.373 & Insignificant \\
\hline Exchange policy & 16 & 0.224 & Insignificant \\
\hline $\begin{array}{l}\text { Convenient } \\
\text { location }\end{array}$ & 12 & 0.676 & Insignificant \\
\hline Reception & 12 & Insignificant \\
\hline Billing Queue & 12 & Insignificant \\
\hline Parking Place & 12 & Insignificant \\
\hline $\begin{array}{l}\text { Wider Choice } \\
\text { Ambience }\end{array}$ & 12 & 0.436 & 0.34 ificant \\
\hline
\end{tabular}

The analysis from the above table number 7 indicates that out of 14 factors only two factors i.e., colour guarantee and comfort sizes have shown significance, remaining 12 alternatives have shown insignificant. This indicates that there is no significant influence of income on consumer Satisfaction. Hence Null Hypothesis is accepted.

Table No: 8

Consumer Satisfaction With Reference To Income Chisquare Analysis

\begin{tabular}{|l|l|l|l|}
\hline Factors & Df & Asymp sig & $\begin{array}{l}\text { Significant/ } \\
\text { Insignificant }\end{array}$ \\
\hline Low price & 12 & 0.602 & Insignificant \\
\hline $\begin{array}{l}\text { Available of } \\
\text { various brands }\end{array}$ & 12 & 0.801 & Insignificant \\
\hline High Quality & 12 & 0.012 & Significant \\
\hline $\begin{array}{l}\text { Comfort sizes } \\
\text { Latest styles } \\
\text { and designs }\end{array}$ & 8 & 0.686 & Insignificant \\
\hline $\begin{array}{l}\text { Color } \\
\text { Guarantee }\end{array}$ & 16 & 0.949 & Insignificant \\
\hline $\begin{array}{l}\text { Discounts and } \\
\text { offers }\end{array}$ & 12 & 0.606 & Insignificant \\
\hline $\begin{array}{l}\text { Exchange } \\
\text { policy }\end{array}$ & 12 & 0.339 & Insignificant \\
\hline $\begin{array}{l}\text { Convenient } \\
\text { location }\end{array}$ & 12 & 0.308 & Insignificant \\
\hline $\begin{array}{l}\text { Reception } \\
\text { Billing Queue }\end{array}$ & 12 & 0.185 & Insignificant \\
\hline
\end{tabular}




\begin{tabular}{|l|l|l|l|}
\hline Parking Place & 16 & 0.776 & Insignificant \\
\hline Wider Choice & 16 & 0.962 & Insignificant \\
\hline Ambience & 12 & 0.573 & Insignificant \\
\hline
\end{tabular}

The analysis from table number 8 indicates that out of 14 factors only one factor i.e., high quality is showing significance. All the remaining 13 factors have shown insignificance. This indicates there is no significant influence of income on consumer Satisfaction. Hence $\underline{\text { Null }}$ Hypothesis is accepted.

It is found that buying behaviour of the customers depends on variety of factors like price, brand, quality, comfort sizes, styles and designs, colour guarantee, discounts and offers, exchange policy, convenient location, reception, billing queue, parking place, wider choice and ambience. Majority of customers are satisfied. It is concluded that age group of 18-22 yrs preferred low prices and availability of brands and are satisfied with High quality and discounts \& offers. Home makers and 20000-40000 income category respondents preferred colour guarantee and comfort sizes. They got satisfied with high quality. Results have indicated that there is no significant influence of age and income on consumer preference and satisfaction.

\section{REFERENCES}

1 Vidya $\mathrm{B}$ panicker, "A brand experience study on the apparel buying behaviour of women consumers in Mumbai", International Journal of Commerce and Management Research, vol. 3, pp. 10-15, 2017.

2 S.Poonagodi. M, "Apparel choice and buying behaviour of college girls", Intercontinental Journal of Marketing Research Review, vol. 5, pp. 8-14, 2017.

3 Tanvi Gupta. J. (2017.vol 13). "Assessment of Demographic impact on female psychographics", KIIT Journal of Management, vol. 13, pp. 1-16, 2017 